\title{
Structural Optimization and Experimental Research of High-rise Guyed Tower
}

\author{
WU Jing ${ }^{1, *}, H A N$ Junke $^{1}, Y E$ Fang $^{2}, Q I$ Wenyan $^{2}, Y U$ Jinshan $^{2}, W E I$ Peng $^{3}$, and XING Haijun ${ }^{1}$ \\ ${ }^{1}$ China Electric Power Research Institute, Beijing, 100055, China \\ ${ }^{2}$ State Grid Tianjin Electric Power Company Electric Power Research Institute, Tianjin, 300384, China \\ ${ }^{3}$ Northwest Electric Power Design Institute of China Power Engineering Consulting Group, Xi'an, 710075, China
}

\begin{abstract}
In this paper, the structural optimization of high-rise guyed tower is carried out for the guyed wire and tower column schemes. The schemes are compared from the four guyed wires and eight guyed wires, the width of the tower column, the uniform cross-section tower column and the variable cross-section tower column, etc. And the single-column tower with eight guyed wires and variable cross-section is recommended for the high-rise guyed tower. Through the full-scale test study of the high-rise guyed tower, the safety of the high-rise guyed tower structural optimization and the feasibility of engineering application are verified. According to the technical and economic analysis of traditional self-supporting towers and high-rise guyed towers recommended in this paper, it can be seen that the weight and total cost of the high-rise guyed towers are $75.3 \%$ and $88.5 \%$ of the traditional self-supporting towers respectively, demonstrating the technical and economic advantages of the high-rise guyed towers. The advantages and disadvantages of high-rise guyed towers and self-supporting towers are summarized for reference in engineering design.
\end{abstract}

\section{Introduction}

The guyed tower has the advantages of clear structural force and economical tower weight. Compared with selfsupporting towers, conventional guyed towers can save $20 \%-40 \%$ of tower materials. Guyed towers have been used at the beginning of the construction of high-voltage transmission line projects in China and other countries. Guyed towers have been widely used in $330 \mathrm{kV}, 500 \mathrm{kV}$ and $750 \mathrm{kV}$ transmission line projects in China ${ }^{[1]}$. The United States, Canada, Argentina, South Africa and other countries also have the engineering application of cable towers in $345 \mathrm{kV}, 500 \mathrm{kV}, 765 \mathrm{kV}$ and $1150 \mathrm{kV}$ voltage level lines, as shown in Figure 1.

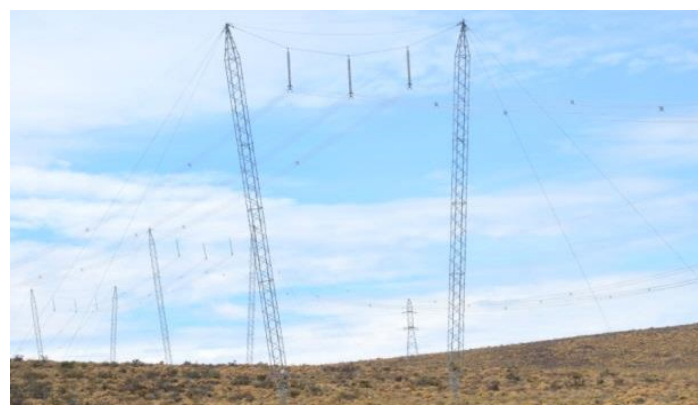

Fig. 1. Guyed tower used in $500 \mathrm{kV}$ line in Argentina

At present, guyed towers are only used in $750 \mathrm{kV}$ line projects and below in China ${ }^{[2-3]}$. Due to the limit of design experience, topographical conditions and other factors, guyed towers have not been used in high-rise or UHV transmission towers. With the increasing load and voltage level of towers, the demand for high-rise towers and economic efficiency increases accordingly. Therefore, it is necessary to carry out relevant research on the design and application of high-rise guyed towers, so as to broaden the application scope of guyed towers, and improve the design level of guyed towers in China. This article mainly focuses on the research on the structural layout and optimization, design parameters, and full-scale test of high-rise guyed towers. The research results will reduce the tower materials by more than $20 \%$ on average. The direct economic benefits are obvious. Considering the processing, transportation, construction and other indirect benefits, its comprehensive benefits will be very significant.

\section{Structural optimization}

Based on the design requirements of concise and economical high-rise guyed towers, a single-column guyed tower for UHV DC lines is proposed, which is mainly composed of guyed wires and a single lattice tower column. As a result, structural optimization research was carried out for guyed wires and tower column.

\subsection{Scheme of guyed wires and tower column}

The setting scheme of guyed wires is a key factor that affects the force state of the guyed tower. Unlike selfsupporting towers, the lateral, longitudinal and torsional stiffness of single-column guyed towers need to be

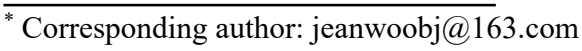


provided by guyed wires ${ }^{[4-5]}$. There are many ways to set up the guyed wires. Four guyed wires can be connected to the tower body through a frame, or eight guyed wires can be directly connected to the tower body. The guyed points can be arranged on the same horizontal plane or in multiple layers. This article mainly plans two schemes of four and eight guyed wires, as shown in Figure 2. The final scheme of the wires should be comprehensively decided according to the tower column.

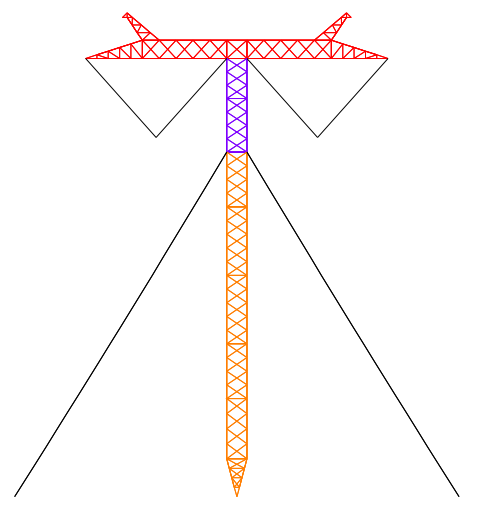

(a) front view

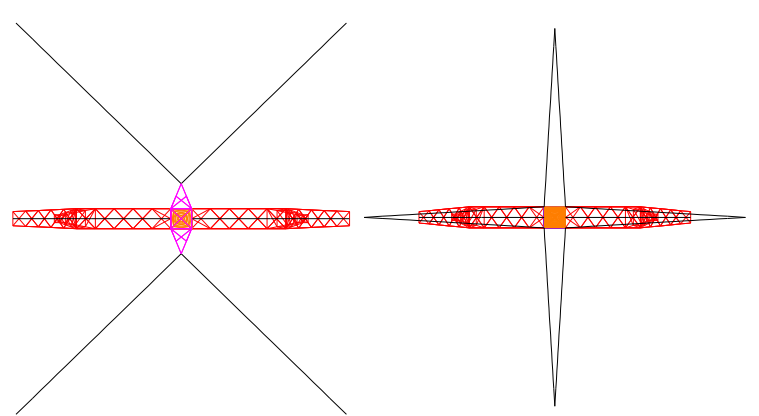

(b) top view(4 guyed wires)

(c) top view (8 guyed wires)

Fig. 2. Guyed scheme of single-column guyed tower

The column of the single-column tower is a lattice tower column, and its cross-section can be rectangular or square. Since the tower column may bear external loads from all directions, in order to ensure that the rigidity of the tower column in all directions is as balanced as possible, a square section is recommended.

The width of the tower column has a great influence on the tower weight. When the specifications of the tower column are fixed, the smaller the column width, the larger the slenderness ratio, and the more unstable the column will be. If the column width is too large, however, material waste will be caused. In this paper, a comparison calculation of the influence of different column widths on the weight of the tower is carried out for single-column towers with four and eight guyed wires, as shown in Table 1. According to the calculation data, the weight of the eight guyed tower is about $5 \%$ lighter than the four guyed tower. Therefore, the single-column tower with eight guyed wires is recommended. And it's more economical when the column width is between $2.8 \mathrm{~m}$ and $3.2 \mathrm{~m}$.

Table 1. The influence of column width on tower weight

\begin{tabular}{|c|c|c|}
\hline $\begin{array}{c}\text { column } \\
\text { width }\end{array}$ & $\begin{array}{c}4 \text { guyed tower weight } \\
(\mathrm{t})\end{array}$ & $\begin{array}{c}8 \text { guyed tower weight } \\
(\mathrm{t})\end{array}$ \\
\hline
\end{tabular}

\begin{tabular}{|c|c|c|c|c|c|c|}
\hline$(\mathrm{m})$ & column & wires & total & column & wires & total \\
\hline 2.6 & 35.112 & 2.630 & 37.742 & 33.470 & 3.325 & 36.795 \\
\hline 2.8 & 35.175 & 2.632 & 37.807 & 32.863 & 3.326 & 36.189 \\
\hline 3.0 & 34.946 & 2.634 & 37.580 & 31.756 & 3.327 & 35.083 \\
\hline 3.2 & 35.616 & 2.635 & 38.251 & 32.390 & 3.328 & 35.718 \\
\hline 3.4 & 36.232 & 2.637 & 38.869 & 33.588 & 3.329 & 36.917 \\
\hline
\end{tabular}

The use of tower column with uniform or variable cross-section along the height of the tower is also an important factor. The force of the tower column can be regarded as a beam with one end hinged and one end elastically supported, and the restraint of the guyed wires on the column can be regarded as an elastic support, as shown in Figure 3. The force of the tower column above the guyed point is more complicated, which bears the vertical load $\mathrm{N}$ from the upper part, the bending moment $\mathrm{M}$ and the torque $\mathrm{T}$ caused by the horizontal load. The tower column below the guyed point is relatively simple and mainly bears bending. And the tower column bending moment $\mathrm{M}$ increases sequentially from bottom to top. The bottom end is 0 , while the largest moment is at the guyed point. Its internal force also increases from bottom to top. Therefore, the variable cross-section column is designed to adapt to this kind of force characteristics. The bottom section of the column is the smallest and the cross-section at the guyed point is the largest. Consequently the force of the main material of each section of the tower column tends to be uniform and the materials are used to the best. So the single-column tower with eight guyed wires and variable cross-section is recommended in this paper, as shown in Figure 4.

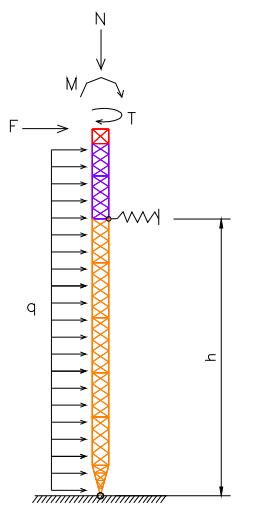

Fig. 3. Forces of column

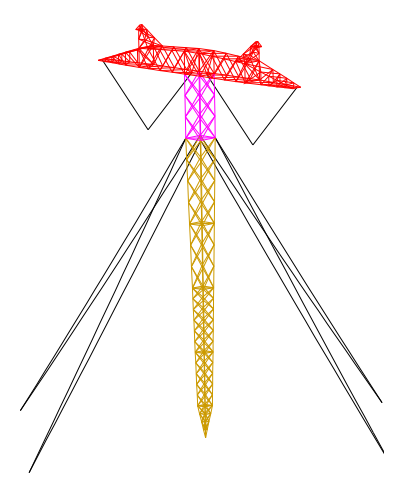

Fig. 4. Tower with variable cross-section column

\subsection{Structural optimization}

Based on the above schemes of guyed wires and tower column, the calculation and comparison for two optimization schemes are carried out. One is the tower with four guyed wires and uniform cross-section column. The other is the tower with eight guyed wires and variable cross-section column. The results are shown in Table 2. 
Table 2. Comparison for schemes of 4 and 8 guyed towers

\begin{tabular}{|c|c|c|c|c|c|}
\hline \multirow{2}{*}{ schemes } & \multirow{2}{*}{$\begin{array}{c}\text { column } \\
\text { width } \\
\end{array}$} & \multirow{m}{}{)} & $\begin{array}{c}\text { tension } \\
\text { of wires } \\
(\mathrm{kN})\end{array}$ & \multicolumn{2}{|c|}{ tower weight $(\mathrm{t})$} \\
\cline { 4 - 6 } & & column & wires & total \\
\hline $\begin{array}{c}4 \text { guyed } \\
\text { tower }\end{array}$ & 3.0 & 1182 & 33.95 & 2.63 & 36.5 \\
\hline $\begin{array}{c}8 \text { guyed } \\
\text { tower }\end{array}$ & $\begin{array}{c}\text { top } 3.0 \\
\text { bottom1.5 }\end{array}$ & 733 & 28.33 & 3.33 & 31.0 \\
\hline
\end{tabular}

From the data in Table 2, it can be seen that the scheme of eight guyed tower with variable cross-section saves more than $15 \%$ of the tower weight than the scheme of four guyed tower with uniform cross-section. And the displacement of each point of the tower body with eight guyed wires is much smaller than the scheme of four guyed tower. Therefore, the suggestions in this article for the optimization for the structure of high-rise guyed tower are as follows:

(1) It is not recommended to use single-column towers with four guyed wires for high-rise guyed towers, which are only suitable for transmission lines with small loads.

(2) It is recommended to apply the single-column tower with eight guyed wires and a variable cross-section tower column.

\section{Full-scale test}

Based on the structural optimization of this paper, a UHV DC transmission line project is selected to carry out a fullscale test of high-rise guyed towers, so as to verify the safety of the high-rise guyed tower structure optimization and the feasibility of engineering application. The test was conducted at the UHV Tower Test Base of the State Grid Corporation of China. The design conditions are as follows:

(1) The design wind speed is $33 \mathrm{~m} / \mathrm{s}$, and the design icing thickness is $10 \mathrm{~mm}$;

(2) Design height is $51 \mathrm{~m}$;

(3) The horizontal range is $480 \mathrm{~m}$, the vertical range is $600 \mathrm{~m}$, and the representing range is $450 \mathrm{~m}$;

(4) The wire type is JL/G3A-1000/45, and the ground wire type is LBGJ-150-20AC.

The full-scale test tower adopts the structural scheme of eight guyed wires and variable cross-section tower column. The maximum column width is $3 \mathrm{~m}$, and the minimum column width is $1.5 \mathrm{~m}$. The guyed wires is $\mathrm{V}$ shaped layout, the wires' height is $42 \mathrm{~m}$, and the angle to the ground is $50^{\circ}$. The test site is shown in Figure 5.

There are 6 kinds of test conditions: broken right ground wire, broken right conductor, anchor right conductor, uneven icing, $90^{\circ}$ wind, $45^{\circ}$ wing. And the $90^{\circ}$ wind is the overload condition, and the test load exceeds $120 \%$ of the design load. The test loads for other conditions are $100 \%$ design load.

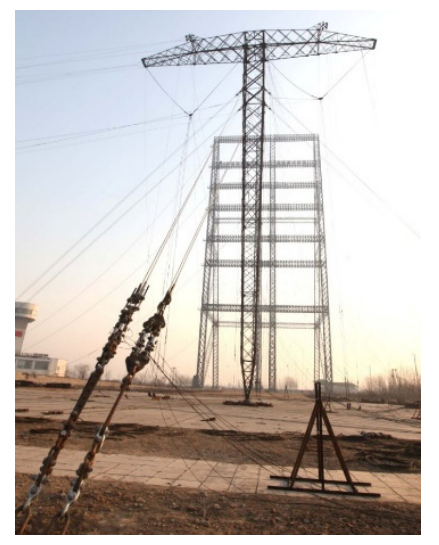

Fig. 5. The site of the full-scale test

The full-scale tower successfully passed the tests of 6 kinds of loads, and it's proved that the optimized design for the high-rise guyed tower structure is safe and reasonable. And such tower is feasible in actual engineering.

Analyzing the internal force of the guyed wires shows that the actual test value of the internal force of the wire in condition 1 is in good agreement with the calculated value, and the difference is less than $8 \%$, as shown in Table 3 . In this table, T1 is the test value, and T2 is the calculated value. Other test conditions are similar. It shows that the calculation result of the internal force of the guyed wire is reliable, and also verifies the safety and rationality of the structural optimization for the high-rise guyed tower.

Table 3. Comparison for internal forces of guyed wires

\begin{tabular}{|c|c|c|c|c|c|c|}
\hline load & \multicolumn{3}{|c|}{ initial tension } & \multicolumn{3}{c|}{ condition 1 } \\
\hline $\begin{array}{c}\text { guyed } \\
\text { wire }\end{array}$ & $\begin{array}{c}\mathrm{T} 1 \\
(\mathrm{kN})\end{array}$ & $\begin{array}{c}\mathrm{T} 2 \\
(\mathrm{kN})\end{array}$ & $\mathrm{T} 1 / \mathrm{T} 2$ & $\begin{array}{c}\mathrm{T} 1 \\
(\mathrm{kN})\end{array}$ & $\begin{array}{c}\mathrm{T} 2 \\
(\mathrm{kN})\end{array}$ & $\mathrm{T} 1 / \mathrm{T} 2$ \\
\hline A & 108.8 & 130 & 0.84 & 36.6 & 35.1 & 1.04 \\
\hline B & 137.0 & 130 & 1.05 & 173.1 & 164.4 & 1.05 \\
\hline C & 131.1 & 130 & 1.01 & 46.1 & 49.8 & 0.93 \\
\hline D & 137.1 & 130 & 1.05 & 240.2 & 241.4 & 0.99 \\
\hline E & 112.1 & 130 & 0.86 & 62.8 & 65.2 & 0.96 \\
\hline F & 143.8 & 130 & 1.11 & 294.9 & 303.9 & 0.97 \\
\hline G & 110.7 & 130 & 0.85 & 40.5 & 42.0 & 0.96 \\
\hline H & 120.0 & 130 & 0.92 & 204.6 & 200.1 & 1.02 \\
\hline
\end{tabular}

Take the overload condition 6 as an example to carry out the analysis of the displacement data of the guyed tower. The displacement measurement points are shown in Fig. 6. The calculated displacements of the tower head and column are relatively close to the actual measured displacement, and the average difference is about $5 \%$, as shown in Table 4. In this table, D1 is the calculated value, and D2 is the test value. Other test conditions are similar. The calculated displacement is consistent with the actual measured result, indicating that the calculation result and deformation trend of the displacement of guyed tower are reliable, and it also verifies the safety and rationality of the structural optimization of the high-rise guyed tower. 


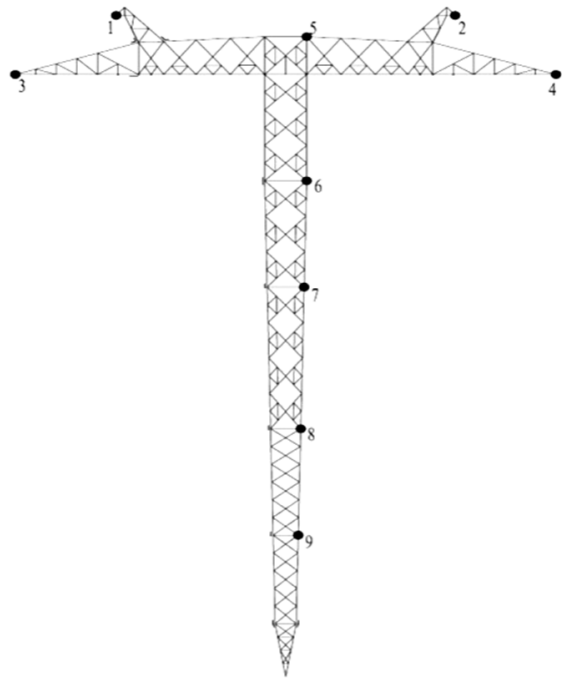

Fig. 6. Test points of displacement

Table 4. Comparison for displacements of tower column

\begin{tabular}{|c|c|c|c|}
\hline $\begin{array}{c}\text { test } \\
\text { points }\end{array}$ & $\begin{array}{c}\mathrm{D} 1 \\
(\mathrm{~mm})\end{array}$ & $\begin{array}{c}\mathrm{D} 2 \\
(\mathrm{~mm})\end{array}$ & $\begin{array}{c}\text { (D1-D2)/D2 } \\
(\%)\end{array}$ \\
\hline 1 & 244 & 225 & 8.44 \\
\hline 2 & 274 & 261 & 4.98 \\
\hline 3 & 291 & 303 & -3.96 \\
\hline 4 & 273 & 302 & -9.60 \\
\hline 5 & 272 & 277 & -1.81 \\
\hline 6 & 253 & 281 & -9.96 \\
\hline 7 & 222 & 258 & -13.95 \\
\hline 8 & 180 & 211 & -14.69 \\
\hline 9 & 120 & 131 & -8.40 \\
\hline
\end{tabular}

\section{Technical economic analysis}

The project consumption and cost are compared between the high-rise guyed tower recommended in this article and the traditional self-supporting tower. The project consumption includes the consumption of tower, foundation, guyed wires and fittings. The cost is calculated according to the standards as follows: tower material 8000 Yuan/t, the guyed wires and fittings 18000 Yuan/t, and the concrete $2200 \mathrm{Yuan} / \mathrm{m}^{3}$. The calculation results are shown in Table 5. In this table, the tower type $\mathrm{S}$ is the selfsupporting tower, and the type $\mathrm{G}$ is the high-rise guyed tower.

Table 5. Comparison of consumption and cost between highrise guyed tower and self-supporting tower

\begin{tabular}{|c|c|c|c|c|c|c|}
\hline $\begin{array}{c}\text { tower } \\
\text { type }\end{array}$ & $\begin{array}{c}\text { tower } \\
\text { weight } \\
(\mathrm{t})\end{array}$ & $\begin{array}{c}\text { weight of } \\
\text { wires\&fi- } \\
\text { ttings(t) }\end{array}$ & $\begin{array}{c}\text { concrete } \\
\left(\mathrm{m}^{3}\right)\end{array}$ & $\begin{array}{c}\text { cost } \\
(\text { Yuan })\end{array}$ & $\begin{array}{c}\text { tower } \\
(\%)\end{array}$ & $\begin{array}{c}\text { cost } \\
(\%)\end{array}$ \\
\hline $\mathrm{S}$ & 41.25 & 0 & 67.24 & 477900 & 100.0 & 100.0 \\
\hline $\mathrm{G}$ & 26.57 & 4.48 & 59.03 & 423000 & 75.3 & 88.5 \\
\hline
\end{tabular}

From the comparative data in Table 5, it can be seen that the tower weight (including the wires and fittings) of the high-rise guyed tower is $75.3 \%$ of the traditional selfsupporting tower, and the total cost is $88.5 \%$ of the traditional self-supporting tower. The technical and economic advantages of the high-rise guyed tower are obvious.

Table 6 lists the advantages and disadvantages of the high-rise guyed towers and self-supporting towers for reference in engineering design.

Table 6. Comparison of advantages and disadvantages of guyed tower and self-supporting tower

\begin{tabular}{|c|c|c|}
\hline $\begin{array}{l}\text { tower } \\
\text { type }\end{array}$ & advantages & disadvantages \\
\hline$S$ & $\begin{array}{l}\text { (1) small footprint } \\
\text { (2) widely used } \\
\text { (3) convenient maintenance }\end{array}$ & $\begin{array}{l}\text { (1) poor torsional stiffness } \\
\text { (2) heavy weight }\end{array}$ \\
\hline $\mathrm{G}$ & $\begin{array}{l}\text { (1) light weight and cost } \\
\text { (2) simple structure } \\
\text { (3) easy construction }\end{array}$ & $\begin{array}{l}\text { (1) large footprint } \\
\text { (2) more maintenance }\end{array}$ \\
\hline
\end{tabular}

\section{Conclusion}

In this paper, the structural optimization of high-rise guyed tower is carried out for the guyed wire and tower column schemes. The schemes are compared from the four guyed wires and eight guyed wires, the width of the tower column, the uniform cross-section tower column and the variable cross-section tower column, etc. And the singlecolumn tower with eight guyed wires and variable crosssection is recommended for the high-rise guyed tower.

Through the full-scale test study of the high-rise guyed tower, the safety of the high-rise guyed tower structural optimization and the feasibility of engineering application are verified.

According to the technical and economic analysis of traditional self-supporting towers and high-rise guyed towers recommended in this paper, it can be seen that the weight and total cost of the high-rise guyed towers are $75.3 \%$ and $88.5 \%$ of the traditional self-supporting towers respectively, demonstrating the technical and economic advantages of the high-rise guyed towers. The advantages and disadvantages of high-rise guyed towers and selfsupporting towers are summarized for reference in engineering design.

\section{References}

1. Li, Z. (2016) Design technology and engineering application for high-rise tower and its foundation. China Electric Power Research Institute, Beijing.

2. Xiao, Z.Z., Wen, H., Li, Z.L. (2017) Research on static stability of $\pm 800 \mathrm{kV}$ suspension cable guyed tower. Journal of northeastern university(natural science), 38: 746-750.

3. Yang, W.G., Zhu, B.W., Qi, L.Z., Wang, Z.Q. (2015) Nonlinear static characters and simplified finite element model of guys in UHV guyed transmission tower. Proceedings of the CSEE, 35: 232-240.

4. Yang, W.G., Chen, X.Y., Wang, Z.Q. (2017) Experimental system on torsional stiffness of main column of UHV guyed tower. Experimental technology and management, 34: 82-85. 
5. Chen, X.Y. (2019) Nonlinear Vibration analysis of cable-beam model of single-mast guyed tower. North China Electric Power University, Beijing. 